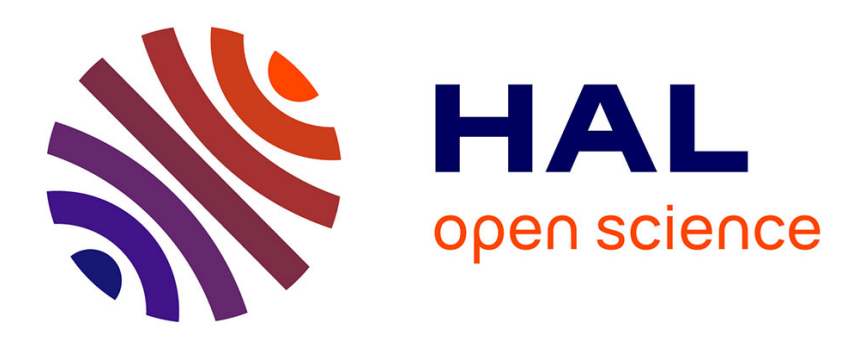

\title{
Acceleration and Time Pathologies
}

Kevin A. Aho

\section{To cite this version:}

Kevin A. Aho. Acceleration and Time Pathologies. Time \& Society, 2007, 16 (1), pp.25-42. 10.1177/0961463X07074100 . hal-00571021

\section{HAL Id: hal-00571021 \\ https://hal.science/hal-00571021}

Submitted on 1 Mar 2011

HAL is a multi-disciplinary open access archive for the deposit and dissemination of scientific research documents, whether they are published or not. The documents may come from teaching and research institutions in France or abroad, or from public or private research centers.
L'archive ouverte pluridisciplinaire HAL, est destinée au dépôt et à la diffusion de documents scientifiques de niveau recherche, publiés ou non, émanant des établissements d'enseignement et de recherche français ou étrangers, des laboratoires publics ou privés. 


\section{Time \\ Society}

\section{Acceleration and Time Pathologies The critique of psychology in Heidegger's Beiträge}

Kevin A. Aho

ABSTRACT. In his Contributions to Philosophy, Martin Heidegger (1999) introduces 'acceleration' as one of the three symptoms - along with 'calculation' and the 'outbreak of massiveness' - of our technological way of 'being-in-the-world'. In this article, I unpack the relationship between these symptoms and draw a twofold conclusion. First, interpreting acceleration in terms of time pathologies, I suggest the self is becoming increasingly fragmented and emotionally overwhelmed from chronic sensory arousal and time pressure. This experience makes it difficult for us to qualitatively distinguish what matters to us in our everyday lives, resulting in a pervasive cultural mood of indifference, what Heidegger (1995) calls 'profound boredom'. Second, by drawing on Heidegger's hermeneutic method, I argue that the practice of mainstream psychology, by adopting the reductive methodology of the empirical sciences, largely ignores our accelerated socio-historical situation, resulting in therapeutic models that have a tendency to construct and perpetuate the very pathologies the psychologist is seeking to treat. KEY WORDS • acceleration • boredom $\bullet$ Heidegger $\bullet$ hermeneutics $\bullet$ psychology

Our hour is the epoch of going-under. (Heidegger, 1999)

In 1881, the physician George M. Beard introduced the phrase 'American nervousness' to capture the emotional flatness and exhaustion from a life 
increasingly mediated by the mechanized acceleration and time pressure of the industrial age. According to Beard, it is not civilization that causes this kind of emotional strain but the unique social forms of modernity itself. 'The Greeks were certainly civilized', says Beard, 'but they were not nervous, and in the Greek language there is no word for the term' (cited in Lutz, 1991: 4; O' Malley, 2005: 385) By the late 19th century, nervousness or 'neurasthenia' had become a ubiquitous symptom of an over-stimulated urban existence. Indeed, it can be argued that emotional exhaustion - emerging in the wake of the technological advent of speed and the compression of time and space - is the most distinctive characteristic of modern living and may represent, what historian Arnold Toynbee calls, 'the most difficult and dangerous of all the current problems [that we face today]' (cited in Ulmer and Schwartzburd, 1996: 329).

One of the historical consequences of an increasingly automated and harried way of life is the proliferation of certain behavioral and mood disorders that, in turn, leads to the emergence and subsequent growth of the mental health industry that treats these disorders. In this article, I suggest that the mainstream mental health professions misunderstand the origins of modern nervousness by interpreting it largely through the procedural lens of the natural sciences privileging the standpoint of detached objectivity and adopting a method that reduces the self to an encapsulated object and human behavior to elemental causal interactions. I argue that this disengaged view overlooks, what Martin Heidegger calls, 'being-in-the-world' or 'Da-sein', our everyday involvement in a social and historical background or 'there' $(D a)$ that tacitly shapes the way we live our lives and interpret our own behavior.

Although Heidegger's decade-long seminars with physicians and psychiatrists in Zollikon, Switzerland (1959-71) ${ }^{1}$ represents his most sustained critique of psychology, I will be focusing my attention on Heidegger's Beiträge zur Philosophie (Vom Ereignis) - translated as Contributions to Philosophy (from Enowning) (1999) - which introduces three overlapping characteristics or 'symptoms' that constitute our technological being-in-the-world: 'calculation', 'acceleration' and 'the outbreak of massiveness' (p. 84). Although much has been written on Heidegger's view of 'calculation' and 'massiveness', particularly in light of his later writings on technology, very little has been made of his conception of 'acceleration', the term used to describe the frantic pace of modern life. By unpacking the relationship between these characteristics I attempt to appropriate from the Beiträge a historically grounded psychology, one that offers a hermeneutic critique of the practice of psychology itself. This critique is based on the fact that mainstream psychology largely overlooks the accelerated historical situation that the client is 'thrown' (geworfen) into, and, as a result, may be unwittingly perpetuating the accelerated patterns of behavior that sparked the client's nervous disorder in the first place. 


\section{Acceleration and the Pathology of Boredom}

Written in 1936-8, Heidegger's Beiträge is considered to be his most important book after Being and Time (1962). The Beiträge consists of six 'joinings' or 'fugues' (Fügungen) which, taken together, repeat the same disclosive movement of western history from different perspectives. ${ }^{2}$ The first fugue, 'Echo', is the primary focus of this project. Echo signals the end of metaphysics, intimating the total withdrawal of the 'question of being' (Seinsfrage) in the age of global technology. According to Heidegger, the distinctively western understanding of being is moving toward its nihilistic endpoint in the technological age. 'Nihilism' occurs when we no longer ask the ontological question concerning the being of beings - of how and why beings manifest or show up as they do - and are instead totally occupied with consuming, exchanging, and producing beings. As Heidegger (2000) says in his 1935 lecture course, Introduction to Metaphysics, '[Today] we encounter beings everywhere; they surround us, carry us, enchant and fulfill us, elevate and disappoint us, but where in all this is the being of beings, and what does it consist in?' (p. 34). In the age of nihilism, the world is understood solely as a vast storehouse of objects to be manipulated, consumed, and quantified by means of 'machination'. With global machination, beings are only to the extent that they are 're-presentable', 'made', or 'can be made' in terms of calculable production and exchange. To this end, beings are revealed or show up in 'lived experience' (Erlebnis) in only one way, as something useful, measurable, and familiar to everyone (Heidegger, 1999).

What is significant in the Beiträge is the way in which our contemporary forgetfulness of the question of being is felt. Heidegger (1999) refers to this feeling as 'shock', a shock accompanied by 'compelling distress' (nötigende Not) (p. 79). However, what is particularly shocking today 'is the lack of distress' itself; our way of living is so active, busy and occupied with things that we have no time for distress (pp. 79, 277, all emphases are from original sources unless otherwise indicated). In order to come to grips with the ways in which modern life embodies a hidden distress we must get a clearer picture of what Heidegger means by the self.

Against the modern view of the self that we inherit from Descartes, Heidegger suggests the human being (Dasein) is not to be interpreted as $a$ being (Seiende), a quantifiable material body or an immaterial mind. Dasein is a shared, sociohistorical 'happening' (Geschehen) or way of being that opens up a horizon or 'clearing' (Lichtung) of intelligibility, a horizon that shapes the way beings are understood and matter to us in our everyday lives. The self, on this view, is always already 'absorbed' (aufgehen) in a public world and is properly understood not in terms of its objective properties but in terms of what it does, 'proximally and for the most part - in [its] average everydayness', such as handling tools, driving to work, surfing the net, shopping (Heidegger, 1962: 16) 
This means I am invariably involved in the acts and practices that 'They' or 'Anyone' (das Man) are involved in. And if I am what I do, then I am an indistinguishable 'Anyone'. I interpret myself as a teacher, a husband, or a homeowner because I have been 'dispersed' (zerstreuen) into the public roles and practices of others. Thus, 'the self of everyday Dasein is a they-self . . . As a they-self, the particular Dasein has been dispersed into the "they" and must find itself' (Heidegger, 1962: 129).

Shaped by a public horizon, we invariably 'fall prey' (Verfallen) to modern assumptions, prejudices, and social fads. In today's turbo-capitalist economy, for instance, the self is interpreted as an autonomous subject who, for the most part, values busy-ness, careerism, and conspicuous consumption. Such public self-interpretations give our lives a sense of security and comfort, providing the illusion of living well because we are 'doing what [everyone else] does' (Heidegger, 1962: 223). In short, our understanding of things is mediated by the world into which we are thrown. The problem today is that we are thrown into a worldview of global machination, a worldview that is totalizing insofar as it 'blocks off' or 'conceals' any other way to interpret beings, including ourselves (Heidegger, 1977a: 33). To this end, the present age 'masters' us to the extent that we are forgetful of the historical values and 'guiding determinations' that preceded it (Heidegger, 1962: 20).

As mentioned earlier, Heidegger's Beiträge identifies three fundamental 'symptoms' of modernity that signal the 'darkening of the world and the destruction of the earth ... calculation, acceleration, and massiveness' (Heidegger, 1999: 83) Calculation is revealed in the way all things in the world are quantifiable and organized in terms of instrumental principles. Through the lens of calculation, the mountain stream shows up as acre-feet of water, the forest as board-feet of lumber, and an office building full of human beings is quantified as 'human resources'. In the technological age, all things are subject to the governing rules of calculation and 'the incalculable is here only what has not yet been mastered' (p. 84) Thus, calculation becomes the 'basic law' of human behavior, where the organic rhythms of life are organized and compressed with schedules and plans, and the day is broken down in terms of the productivity of hours, minutes, seconds, and even tenths-of-seconds. Indeed, in today's global economy, where mere fractions of seconds can translate into the gain or loss of hundreds of thousands of dollars, the rules of calculation are increasingly regulated by a second symptom of the modern age, acceleration.

Acceleration captures the ways in which our everyday life involves a relation to speed, a frenzied tempo or 'mania' embodied in the current tendency of 'notbeing-able-to-bear the stillness' (Heidegger, 1999: 84): '[It is] the mania for what is surprising, for what immediately sweeps [us] away and impresses [us], again and again and in different ways' (p. 84). This mania is exhibited in everyday body comportments that are shaped by what social psychologist Robert 
Levine (1997) calls 'time urgency'. Levine suggests that the accelerated self can be identified as one who continually glances at his/her watch and checks his/her cell phone; speaks quickly and becomes frustrated when someone takes too long to make a point; eats, walks and drives fast and becomes angry when caught in slow-moving traffic; is compulsively punctual and follows lists and schedules to manage his/her day; and finds it difficult to wait in line or sit still without something or someone to distract or occupy him/her.

As a consequence, acceleration reveals a unique relation to time. In the course of my everyday life, I am captivated with or 'entranced' by the exciting things I encounter 'now'. For Heidegger (1995), living in the 'now' leaves me in a constant state of 'limbo' because I am unable to ask how or why I am captivated with particular things and where this captivation might take me:

This letting oneself go with whatever is happening around us is possible only if, from the outset, we constantly let whatever is going on come toward us, come up against us, just as it is given. It is possible only if we are entirely present [ganz Gegenwart $]$ in the face of whatever is happening around us, or, as we say, only if we simply make present [gegenwärtigen]. (p. 124)

Being caught up in the Present (Gegenwart) cuts me off from an authentic awareness of, what Heidegger calls, 'primordial temporality'. ${ }^{3}$ To the extent that the accelerated self is absorbed in the 'now', I forget how my life is shaped by the past and the future, by the temporal structures of 'situatedness' (Befindlichkeit) and 'projection' (Entwurf). Situatedness refers to the past insofar as I am always already 'thrown' into a socio-historical situation that determines how things affect me in terms of certain temperaments or moods. Projection refers to the future insofar as I am always 'ahead-of-[my]self' (sich vorweg) as I ceaselessly 'run forward' into possibilities, into already available social roles, practices, and identities, until my greatest ownmost (eigenst) possibility, death (Heidegger, 1962). Busily captivated by the 'Present', I forget that I am a 'thrown project'; I forget the 'Past' (Gewesenheit) and the 'Future' (Zukunft), that is where my everyday self-interpretation comes from and where it is heading. Consequently, says Heidegger (1962), 'the Present leaps away from its authentic future and from its authentic having been' (p. 348).

To this end, the symptom of acceleration reveals a self that is fragmented and disjointed to the extent that it is pulled apart by competing commitments and investments that are always, for some reason, urgent. Ironically, this kind of fragmentation can often be experienced most intensely on days of 'leisure'. As I wake up on a sunny Saturday morning, I have no obligation to go to the office but I am still pulled into the 'now' as a jumble of pressing possibilities. I must wash the car, mow the lawn, pick up the dry cleaning, check my email, go for a jog, buy groceries, pay the bills, and if I finish these tasks I can watch the football game in the evening. By day's end I am not relaxed and contented but 
exhausted, wondering where the day went. Thus, as Kenneth Gergen (1991) points out, the paradox of accelerated living is that it does not result in exhilarating satisfaction but often with a feeling of being defeated and overwhelmed. This feeling of defeat is prompted by, what cardiac psychologists Diane Ulmer and Leonard Schwartzburd (1996) call, 'hurry sickness', referring to a self that suffers from 'severe and chronic feelings of time urgency that have brought about changes affecting personality and lifestyle' (p. 331). The self is caught in a repeating cycle of behavior, a 'time pathology' that nervously hungers for more things, more distractions, and interprets his/her self-worth in terms of quantitative accomplishments and the accumulation of material goods. Drawing on over two decades of clinical experience, Ulmer and Schwartzburd identify three areas in which acceleration affects the self in detrimental ways. First, in terms of physical health, the experience of time pressure and chronic sensory arousal contributes to the proliferation of heart disease, high blood pressure, obesity, emotional fatigue, insomnia and increasing tendencies toward hostility and rage. Second, in a social or interpersonal sense, acceleration contributes to the fragmentation of relationships and the emotional support systems of family and friends which take time to develop and sustain, leading to an increasing sense of isolation and loneliness. Finally, on a psychological level, Ulmer and Schwartzburd identify a general mental state associated with acceleration that has 'received little attention in the empirical literature', a mood described as 'a personal, perhaps even spiritual, barrenness or emptiness spawned by the chronic struggle to accomplish tasks, which can lead to a rather joyless existence and give rise to covert self-destructive behaviors' (p. 332). According to Heidegger, the accelerated self is, quite simply, suffering from 'boredom' (Langeweile). Thrown into a harried world, we are so nervous, so sped up that we become indifferent, unable to qualitatively distinguish which choices, commitments, and obligations are significant or matter to us.

Although 'anxiety' (Angst) is the mood that receives the most attention in Being and Time (1962), in his 1929-30 Freiburg lecture course, The Fundamental Concepts of Metaphysics (1995), Heidegger offers an analysis of the mood that best captures the temperament of accelerated living, 'boredom'. ${ }^{5}$ In these lectures, Heidegger distinguishes between three kinds of boredom: 'becoming bored with something' (Gelangweiltwerden von etwas), 'being bored by something' (Sichlangweilen bei etwas), and 'being bored' (Sichlangweilen) itself. ${ }^{6}$ The first kind of boredom is the ordinary conception, referring to how I encounter or find certain things or situations. For instance, I may 'become bored with' a particular book, a long drive, or waiting for a flight in the airport. Indeed, I can even find myself boring. When I am bored with something, I feel uninterested, 'indifferent', and 'depressed', and I must find a way to 'while' (Weile) away the time (Heidegger, 1995: 117). ${ }^{7}$ This feeling of indifference is 'conspicuous' insofar as it has an object; I am bored with such and such. 
Consequently, this form of boredom is 'halting' or transient insofar as it comes and goes in the course of my life. For instance, once my plane takes off after waiting in the airport I am no longer bored. To this end, "what is boring comes from outside ... A particular situation with its circumstances transposes us into boredom' (p. 128).

This kind of conspicuous boredom is contrasted with a second, more profound kind. 'Being bored by something' is less obtrusive than the first kind of boredom because it emerges when I make no effort to 'while away' the time. Heidegger (1995) gives the example of a dinner party filled with good food, music, and conversation. At the party, I do not notice myself 'killing time' because I am caught up in the 'now', in the activities and gossip of the social event. When I am absorbed in these kinds of public pastimes, it is difficult for me to notice my own boredom. In the shared moment, I am doing - eating, drinking, laughing, singing - what 'anyone' (das Man) and everyone does. Thus, this type of boredom remains hidden and inconspicuous. It is, as Heidegger says, 'admittedly hard to find, and this is precisely because it presents itself in a public manner' (p. 112). Indeed, it is only after I return home that I realize I was bored the whole time, yet I cannot point to a particular conspicuous thing that made the party boring. The party as a whole was boring. It just took up time. Hence, this more profound kind of boredom does not refer to the way we encounter particular things. Rather, it arises inconspicuously in our involvement in certain public situations, therefore it does not come from outside: it arises from out of Dasein itself' (p. 128).

Although the second form of boredom is more primordial than the first to the extent that it conceals itself, it is similar to the first form insofar as it is situational; it lingers for a while and then goes away. This is to be contrasted with the third, most profound kind of boredom, one that is no longer situational but refers to the mood of the modern world itself, the entire socio-cultural horizon that we are currently involved in. Heidegger (1995) says, 'being bored' or 'profound boredom' (tiefe Langeweile) designates that 'it is boring for one'. The 'It' (Es), in this case, is the totality of social relations that make up the world; it is 'beings as a whole' (p. 134, 138). Profound boredom, in this regard, is not transient; it does not come and go but rather captures the fact that the world itself is boring, and 'everyone' is bored. In this regard, profound boredom does not refer to my own private, emotional states which are affected by a conspicuous thing or an inconspicuous situation. In profound boredom, 'we are elevated beyond the particular situation in each case and beyond the specific beings surrounding us' (p. 137). Profound boredom, therefore, is regarded as a structural feature of modern existence itself, a characteristic of our 'situatedness' (Befindlichkeit).

Again, situatedness, our 'where-we're-at-ness' ${ }^{8}$ refers to the way in which we find ourselves invariably thrown into a shared world that attunes or affects us in terms of public 'moods' (Stimmung). Because I always find myself in a situ- 
ation that matters to me, I am already 'attuned,' already in a mood (Heidegger, 1962: 137). Thus, for Heidegger, the German word Stimmung is not, at its deepest level, to be understood subjectively, in terms of my own individual feelings or 'states-of-mind'. Rather, Stimmung is the condition for the possibility of these individual states of mind. ${ }^{9}$ This means boredom is not in $m e$; boredom is already 'out there'. It is the shared 'atmosphere' I have been thrown into, an atmosphere that opens up or discloses in advance the way things and experiences will affect me psychologically and emotionally. Heidegger (1995) explains:

It seems as though a [mood] is in this case already there, so to speak, like an atmosphere in which we first immerse ourselves in each case and which then attunes us through and through. It does not merely seem so, it is so; and, faced with this fact, we must dismiss the psychology of feelings, experiences, and consciousness. (p. 67)

As a fundamental attunement or 'ground-mood' (Grund-Stimmung), profound boredom refers to an ontological condition that attunes the accelerated self in the technological age, a self that continually seeks to be filled up with things and is immersed or 'swept away' in 'whatever is going on or happening around [it]' (p. 124).

Profound boredom becomes ubiquitous because all I do is 'pass the time' with the various things that occupy and consume me during the day. My whole life is organized and managed in terms of busily 'driving away whatever is boring' by means of filling up an underlying feeling of indifference or emptiness through constant activity: work, eating out, exercising, traveling, and shopping. Heidegger (1995) refers to activity that is endlessly dispersed in the production and consumption of things as 'self-forming emptiness' (p. 126). The historian of psychology, Philip Cushman (1990), agrees with Heidegger, describing the 'empty self' as one

[who] seeks the experience of being continually filled up by consuming goods, calories, experiences, politicians, romantic partners, and empathic therapists in an attempt to combat the growing alienation and fragmentation of its era. [It] is dependent on the continual consumption of nonessential and quickly obsolete items or experiences ... accomplished through the dual creation of easy credit and a gnawing sense of emptiness in the self. (p. 601)

On Heidegger's view, the empty self is 'anyone and everyone', and because it is so pervasive our own emptiness remains hidden from us; it is, as Heidegger (1995: 127) says, 'peculiarly inconspicuous'.

The modern self, therefore, does not even know that it is bored because it has grown into a temperament of boredom. This makes profound boredom doubly oppressive. Initially, the frantic pace of modern life makes it increasingly difficult for us to distinguish which choices and commitments actually matter to us 
in our lives. And when we cannot distinguish what matters we become indifferent. Everything is equally important because nothing stands out, nothing matters. 'In this ennui', says Heidegger (1973), 'nothing appeals to us anymore; everything has as much or as little value as everything else, because a deep boredom penetrates our existence to the core' (pp. 50-1).

Yet, on a more profound level, we are oblivious to our own indifference because this is what it means to be in the modern world, '[because] what is boring is here diffused throughout the particular situation as a whole, it is far more oppressive - despite its ungraspability. It oppresses in and during the inconspicuous way in which we are held at a distance in our passing the time' (Heidegger, 1995: 128). As a result, the more profound the boredom, 'the more silent, the less public, the quieter, the more inconspicuous, and wide-ranging it is' (p. 134). And the boredom of the technological age has become so powerful, so pervasive that the accelerated self 'no longer has any power against it' (p. 136). When the world as a whole shows up as a totality of instrumental things to be consumed, produced, and exchanged in order to 'pass the time', then everything is swallowed by indifference, including human beings: 'All of the sudden everything is enveloped and embraced by this indifference. Beings have - as we say - become indifferent as a whole, and we ourselves as these people are not excepted' (p. 138). This totalizing aspect of profound boredom points to the third concealment of the present age, 'the outbreak of massiveness'. In the Beiträge, Heidegger (1999) suggests that the accelerated self has become enfeebled because 'the unfettered hold of the frenzy of the gigantic has overwhelmed him under the guise of "magnitude" (p. 6). Today, we are living in the reign of 'the gigantic' (das Riesenhafte). The world emerges as a global network of compressed, hyper-fast relations that constantly pull us 'everywhere and nowhere all at once', where 'everything gets lumped together into a uniform distancelessness' (Heidegger, 1971: 166).

For Heidegger, the reign of 'the gigantic' has its roots in the ancient Greek conception of technology, understood as techne. Initially, according to Heidegger, techne was conceived in terms of a harmony or rapport with nature, of gently 'releasing' that which is 'brought forth' to become the very thing that it is. For instance, the Greek craftsman was, for Heidegger, one who builds 'the old wooden bridge' that 'lets the river run its course' (Heidegger, 1977a: 17; 1977b: 330). ${ }^{10}$ This is opposed to techne in the modern age, where the hydroelectric plant forces the river into a reservoir, into 'water power'. The accelerated outbreak of massiveness occurs when all beings are forced to come out of concealment in only one way, as a calculable, exchangeable resource, a 'standing reserve' waiting to be consumed, 'challenged' (Herausfordern) and 'enframed' (Gestell). (Heidegger, 1977a: 5, 19) It is for this reason, says Heidegger (1999), that the reign of the gigantic 'drives out every other possibility of revealing' (p. 91). 
Today, the accelerated self is 'bewitched, dazzled and beguiled' by the total domination of the gigantic, soothed by the frenzy of usable, consumable beings (Heidegger, 1966: 56). Heidegger (1999) suggests that the reign of the gigantic is one where we are all in a state of restless 'enchantment' with beings to the point that we can no longer protect ourselves from enchantment: 'One has only to know from where the enchantment comes. The answer: from the unrestrained domination of machination. When machination finally dominates and permeates everything, then there are no longer any conditions by which to detect the enchantment and to protect oneself from it' (p. 87). Thus, enchantment with beings - rooted in calculative and accelerated ways of being - comes 'to be accepted and practiced as the only way' of being (Heidegger, 1966: 56). It is for this reason that the accelerated self is in danger of living a fundamentally barren life, one that pathologically seeks to fill an underlying emptiness.

\section{Acceleration and Modern Psychology: A Hermeneutic Critique}

How can the practice of psychology break through the illusion that our busy enchantment with beings may be a product of indifference with the world as a whole, an indifference that blocks off and denies any other understanding of being? The concern is that the modern self is dispersed and scattered among consumable beings, and, as a result, it is in on the verge of total fragmentation, with no cohesive, unifying sense of who it is. This is precisely why, according to Cushman (1990), the frantic cycles of consumption continue:

This is a powerful illusion. And what fuels the illusion, what impels the individual into this illusion, is the desperation to fill up the empty self ... It must consume in order to be soothed and integrated; it must 'take in' and merge with a self-object celebrity, an ideology, or a drug, or it will be in danger of fragmenting into feelings of worthlessness and confusion. (p. 606)

The situation is particularly troubling if we understand that mainstream psychology largely overlooks the social and historical conditions that create this modern sense of fragmentation by uncritically adopting the disengaged and mechanistic perspective of the natural sciences.

Understood as 'the science of mental processes and human behavior', the discipline of psychology is a historical outgrowth of the 18th-century paradigm of the natural sciences in two fundamental ways. First, psychology is concerned with a specific 'method' or procedure based on the observation of material objects in causal interaction, interaction that can be empirically tested and systematically quantified, resulting in the discovery of general laws. In this regard, modern psychology attempts to reduce behavior to elemental causes that are measurable, testable, and repeatable. Indeed, as Bertrand Russell (1956) suggests, one of the 
goals of psychology was to develop 'a mathematics of human behavior as precise as the mathematics of machines' (p. 142; see also Gergen, 1973). Second, psychology seeks a perspective of detached objectivity, what Thomas Nagel (1979: 208) calls, a 'view from nowhere' that is free from the distortions and misleading assumptions of everyday life. This disengaged perspective downplays the fact that our emotional well-being is largely shaped by a concrete social and historical context, focusing instead on the physical pathology of the individual. From this standpoint, psychology is left with a very narrow approach to therapy, one that is concerned with 'repairing damage within a disease model of human functioning' (Seligman and Csikszentmihalyi, 2000: 5).

In his Zollikon Seminars, Heidegger (2001) maintains that all of the various manifestations of modern psychology, including psychoanalysis, are held under 'the dictatorship' of the scientific method that reduces human behavior to elemental causal interactions and views emotional suffering from the perspective of detached objectivity. Freud (1964) confirms Heidegger's criticism when he claims 'psychoanalysis must accept the scientific Weltanschauung' (my emphasis) because 'the intellect and the mind are objects for scientific research in exactly the same way as non-human beings . . . Our best hope for the future is that intellect - the scientific spirit, reason - may in the process of time establish a dictatorship in the mental life of man' (p. 171; see also Askay, 2001).

Today, the 'scientific spirit' has emerged as psychopharmacology, which has replaced psychoanalysis as the dominant therapeutic model. On this view, the psychiatrist invariably refers to the Diagnostic and Statistical Manual of Mental Disorders (DSM-IV; APA, 1994), a document that catalogues a massive list of observable pathologies, identifies various symptoms, and prescribes ways in which to treat the causes of these symptoms. A client, for instance, with observable symptoms of depression is prescribed medication in order to fix the biologically determined cause, specifically, the chemical levels of serotonin and dopamine in the brain. The medication will balance these levels, block out the feelings of depression and emptiness, and allow the client to effectively and functionally re-enter his/her rapid-paced world. This approach to therapy is problematic.

First of all, psychopharmacology, like psychoanalysis, presupposes a conception of the self that is, in no way, trans-historical. It is a conception rooted in uniquely modern assumptions of individualism and causal determinism (Taylor, 1988; Cushman, 1990). The therapist interprets the client as an encapsulated thing or object that needs to be fixed by means of instrumental techniques and fails to address the underlying socio-historical etiology that may be contributing to the client's disorder. Furthermore, the therapist interprets the mental health of the client largely in terms of his/her competence in handling the frantic pace of modern life, and this has a tendency to perpetuate the very social conditions that manifested the feelings of indifference and emptiness in the first place. (Taylor, 
1988; Cushman, 1990). In short, by ignoring the fact that the practice of psychology itself and the emotional conditions that it treats are shaped by our involvement in a particular social and historical situation, our own emptiness, as Heidegger (1995) says, continues to remain hidden from us.

Indeed, it can be argued that many of the newest illnesses in the latest DSM are a direct result of accelerated social conditions. Among these we might include: (1) the most ubiquitous anxiety disorders mediated by chronic sensory arousal and time pressure, such as 'panic disorder', 'generalized anxiety disorder', and 'social phobia'; (2) personality disorders perpetuated by a culture that values rapid multi-tasking and racing thought patterns, such as 'obsessivecompulsive personality disorder' and 'attention deficit/hyperactivity disorder'; and (3) impulse disorders based on socially determined expectations of instant satisfaction or gratification, such as 'pathological gambling and shopping disorder', 'kleptomania', and 'intermittent explosive disorder'. The mechanistic approach to curing these illnesses results in a paradox if what is causing the disorder is itself an accelerated, mechanized way of living.

The way therapy is provided today illustrates this paradox. With market forces and health trusts imposing time restraints on patient visits, today's psychiatric sessions are increasingly compressed and mediated by assumptions of efficiency and cost-effectiveness, where the therapist is there to either quickly teach the client cognitive-behavioral techniques or prescribe and refill psychotropic medication. Thus, by overlooking the way in which the practice of psychology itself is shaped by an accelerated world, psychologists and psychiatrists have not only been treating the accelerated self, "they have also been constructing it, profiting from it, and not challenging the social arrangement that created it' (Cushman, 1990: 609).

Even alternative forms of therapy that do not focus on the pathological condition of the client fail to articulate the fundamental role that our socio-historical situation plays in determining emotional well-being. Charles Guignon's (2002) critique of the renewed interest in 'positive psychology' is a case in point. ${ }^{11}$ Positive psychology is defined as "a science of positive subjective experience, positive individual traits, and positive institutions [that] promises to improve the quality of life and prevent the pathologies that arise when life is barren and meaningless' (Seligman and Csikszentmihalyi, 2000: 6). To this end, positive psychology does not address the observable symptoms of the disorder. Rather, it embraces the active agency of the client who now focuses his/her energies not on the dark moods of emptiness and ennui but on the positive and optimistic qualities of life, even if such qualities are simply illusions: 'One of the most impressive findings . . . of positive psychology is that positive illusions and unrealistic optimism are in fact beneficial to people, helping them cope with stressful events and extending their lives' (Guignon, 2002: 86). This refocusing on positive illusions will allow the client to interpret himself/herself as a 'deci- 
sion maker with choices, preferences, and the possibility of becoming masterful [and] efficacious' (Seligman and Csikszentmihalyi, 2000: 8).

What remains problematic is that the optimistic values promoted by positive psychology are not timeless; they are themselves products of a technological economy aimed at efficacy and quick-fixes. For instance, as Guignon (2002) points out, the client does not embrace the positive virtues of Aristotle's Nicomachean Ethics such as shame, wittiness, pride, and courage, nor does he/she focus on the Judeo-Christian virtues of humility, selflessness, and meekness. Rather, the psychologist asks the client to focus on uniquely modern values that accommodate the interpretation of the self that psychology inherits from Cartesian and empiricist epistemologies. Thus, the self is interpreted as an enclosed, masterful, autonomous subject that can manipulate and effectively control surrounding objects. This leads the client of positive psychology to focus on values such as 'self-determination' (Schwartz, 2000), 'adaptability' (Vaillant, 2000), 'creativity' (Simonton, 2000), and 'individual happiness' (Buss, 2000).

In doing so, the now optimistic and self-assertive client will be empowered, able to master the accelerated work-world as an effective and optimally functioning individual. This means, however, that the therapist fails to acknowledge the fact that the client's positive values are themselves socially and historically constructed. This results in a twofold dilemma. First, the therapist overlooks the possibility of older, alternative virtues that are part of our shared history such as communal belongingness, attachment, and dependency in favor of ultra-modern individualism and autonomy. The therapist, therefore, is unable to address the client's contemporary experience of isolation and emptiness because the client continues to interpret himself/herself as a self-reliant subject who is cut off from the world rather than someone who belongs to it. Furthermore, by uncritically adopting the values of a technological economy, positive psychology reinforces the same instrumental, accelerated way of living that initially brought about the client's feelings of emptiness.

To this end, Heidegger's project reveals how psychology continues to 'misinterpret' the self as either a masterful, subjective consciousness or a quantifiable, causally determined object. 'I am always disturbed by [psychology's] misinterpretation of being-in-the-world', says Heidegger (2001: 271), 'it is conceived either as a present-at-hand [thing] or as the intentionality of subjective consciousness'. For Heidegger, psychology is called to acknowledge the ontological fact that the self is always already 'being-in-the-world', and it is this ongoing involvement in the world that makes possible the modern interpretation of the self. This is why understanding human existence in terms of Dasein can be so helpful to psychology. With Heidegger, the world is not interpreted as a container filled with objects within which the self resides. Rather, the world is a meaningful nexus of social relations, and the self is already concretely involved with and embedded in this nexus. As Heidegger (1982) says, 'self and world 
belong together in the single entity, the Dasein. Self and world are not two beings, like subject and object, or I and thou, but self and world are the basic determination of the Dasein itself in the unity of the structure of being-in-theworld' (p. 318).

By dismantling the philosophical assumptions of the modern worldview, Heidegger shows us how the practice of psychology can be enhanced by focusing on the socio-historical aspect of the manifestation of individual pathologies. Modern psychology, on this view, does not discover timeless principles of human behavior. The therapeutic practice of psychology itself is a historical phenomenon, the result of an increasingly accelerated, mechanized, and individualistic way of life that began to take hold in the late 19th century, a way of life that brought with it its own brand of emotional malaise. Turn-of-the-century philosophers and social theorists, like Heidegger, responded to this cultural transformation by introducing and redefining terms - such as anxiety (Kierkegaard), boredom (Simmel), alienation (Marx), disenchantment (Weber), the mass man (Ortega y Gasset) and anomie (Durkheim) - in order to engage these emerging pathologies. Thus, in order to properly understand the self, psychology must come to grips with the movement of history that shapes the understanding of who we are. Indeed, 'to understand history', as Heidegger (1997: 7) reminds us, 'cannot mean anything else than to understand the self'.

\section{Conclusion}

We can summarize Heidegger's contribution to modern psychology in the following way. First, by identifying interconnected 'symptoms' of modernity in the Beiträge - 'calculation', 'acceleration', and 'massiveness' - Heidegger (1999) reveals how the frenzied pace of technological life embodies a 'hidden distress' in the inconspicuous cultural mood of boredom. By emphasizing a standpoint of detached objectivity, psychology overlooks the social forms that manifest this shared feeling of indifference and fails to recognize the ways in which the modern self drives away this indifference with the frantic consumption and production of goods and services. This disengaged perspective makes it all but impossible for psychologists and psychiatrists to recognize how they participate in the construction of the accelerated self.

Second, by emphasizing how our everyday understanding of things as well as our moods and dispositions are always already mediated by a socio-historical situation, Heidegger deconstructs the modern conception of the self as an autonomous subject or a biologically determined object. He, therefore, undermines the traditional interpretation of the detached therapist who neutrally examines the objective symptoms of the client. By uncritically adopting this interpretation, psychology neglects the concrete situation that is already there, 
shaping the emotional state and comportment of client and therapist alike. Heidegger reveals that the therapist is, first and foremost, not a disengaged spectator but a 'being-in-the-world', pre-theoretically involved in the public practices and assumptions of modernity. In this regard, the self is what Heidegger calls, 'ex-static'. As human beings, we 'stand outside' of ourselves because we are already woven to the particular worldly context - of equipment, institutions, habits, and prejudices - that we are involved in everyday.

Finally, and perhaps most importantly, Heidegger's project opens up the possibility for mainstream psychology to broaden its approach to treatment by incorporating a wide-ranging historical and cultural understanding of individual pathologies (Cushman, 1995; Dreyfus and Wakefield, 1988; Askay, 2001; Guignon, 2002). This understanding enables the psychologist to break free from, what Heidegger (2001) calls, 'scientism', where science is dogmatically accepted as 'the new religion' insofar as its method alone can provide us with the objective truth about human behavior (p. 18). In his Zollikon Seminars Heidegger (2001) explains, 'science is, to an almost incredible degree, dogmatic everywhere, that is, it operates with preconceptions and prejudices which have not been reflected on. There is the highest need for doctors who think and do not wish to leave the field entirely to the scientific technicians' (p. 103).

By regarding the human being as 'an object which is present-at-hand', psychology ignores our ontological character, that prior to any objectification, we are a finite, socio-historical way of being, a way of being that opens up the Dasein, the 'clearing' or 'there' that makes any worldview, scientific or otherwise, possible. Heidegger's hermeneutic approach to psychology reveals the extent to which science is always already grounded in an unfolding historical horizon. Such an approach can release the therapist from the dogmatic prejudices of the scientific method and release the client from an increasingly narrow definition of the self that is rooted in modern assumptions of individualism, selfreliance, and busyness. It is largely on the basis of these assumptions, after all, that the contemporary experiences of isolation and nervous indifference manifest, leading so many into therapy in the first place.

\section{Notes}

A draft of this article was presented to the American Society for Philosophy, Counseling, and Psychotherapy (ASPCP) at the American Philosophical Association Central Division Meetings in Chicago, April 2006.

1. These seminars began in September of 1959 as a series of lectures with Heidegger and psychiatrists from the University of Zurich's medical clinic, Burghölzli. The seminars later moved to the house of one of Heidegger's close friends, the psychiatrist Medard Boss, who lived in Zollikon. See Aho (2005) for further discussion of 
the importance of the Zollikon Seminars and the role they play in Heidegger's project of fundamental ontology.

2. Besides 'Echo', Heidegger lists 'Playing-Forth', 'Leap', 'Grounding', 'The Ones to Come', and 'The Last God' as the other fugues. These fugues are not to be understood as progressive or chronologically ordered, but as repetitions of the same movement of history or 'be-ing', which Heidegger (1999) refers to with the 18th-century orthography Seyn:

In each of the six joining the attempt is made always to say the same [das Selbe] of the same, but in each case from within another essential domain of that which enowning names. Seen externally and fragmentarily, one easily finds 'repetitions' everywhere. But what is most difficult is purely to enact in accord with the jointure, a persevering with the same, this witness of genuine inabiding of inceptual thinking. (p. 57)

3. Heidegger dismantles the ordinary interpretation of time, understood as a linear 'process' (Vorgang) or sequence of 'nows' that can be measured and organized by means of clocks and calendars into hours, days, weeks, and years. For Heidegger, everyday 'clock time' is itself made possible by 'primordial time', understood as an interconnected manifold of the 'ecstatic' structures of Past (Gewesenheit), Present (Gegenwart) and Future (Zukunft). These structures represent the a priori scaffolding or frame of reference on the basis of which things can show up as the very things that they are.

4. According to Ulmer and Schwartzburd (1996), hurry sickness can be diagnosed if the subject suffers from, among other things: (1) 'deterioration of the personality, marked primarily by loss of interest in aspects of life except those connected with achievement of goals and by a preoccupation with numbers, with a growing tendency to evaluate life in terms of quantity rather than quality'; (2) 'racing mind syndrome, characterized by rapid, shifting thoughts that gradually erode the ability to focus and concentrate and create disruption of sleep'; (3) 'loss of ability to accumulate pleasant memories, mainly due to either preoccupation with future events or rumination about past events, with little attention to the present' (p. 332).

5. This course expands on Heidegger's inaugural Freiburg lecture given on 24 July 1929 entitled 'What Is Metaphysics?' In this lecture, the mood of boredom is explored for the first time.

6. Here I am indebted to Emad (1985) for the thorough analysis of Heidegger's conception of boredom.

7. To this end, the German word for boredom captures something that the French or English renditions cannot. Langeweile is literally the unpleasant mood that accompanies an empty stretch of time; it is 'the lengthening and lingering of the while (Weile)'. See Emad (1985: 67).

8. This translation is taken from Hubert Dreyfus (1991) who suggests that the term conveys 'being found in a situation where things and options already matter' (p. 168).

9. See Aho (2006) for a more involved discussion of Stimmung and the ways in which it shapes our own emotional states.

10. Heidegger (1999) confirms this shift from the pre-modern to modern manifestation of techne in the Beiträge when he writes:

What happens to nature in technicity, when nature is separated out from beings 
by the natural sciences? The growing - or better, the simple rolling unto its end - destruction of 'nature'. What was it once? The site for the moment of the arrival and dwelling of gods, when the site - rested in the essential swaying of be-ing. (p. 195)

11. For instance, the journal American Psychologist recently devoted an entire volume $(55 / 1,2000)$ to the resurgent movement of positive psychology.

\section{References}

Aho, Kevin (2006) 'Metontology and the Body-Problem in Being and Time', Auslegung 28(1): 1-20.

Aho, Kevin (2005) 'The Missing Dialogue between Heidegger and Merleau-Ponty: On the Importance of the Zollikon Seminars', Body and Society 11(2): 1-23.

American Psychiatric Association (APA) (1994) Diagnostic and Statistical Manual of Mental Disorders (4th edn). Washington, DC: APA.

Askay, Richard (2001) 'Heidegger's Philosophy and Its Implications for Psychology, Freud, and Existential Psychoanalysis', in M. Heidegger Zollikon Seminars: Protocals, Conversations, Letters, pp. 301-15. Evanston, IL: Northwestern University Press.

Buss, David M. (2000) 'The Evolution of Happiness', American Psychologist 55(1): 15-23.

Cushman, Philip (1990) 'Why the Self Is Empty: Toward a Historically Situated Psychology', American Psychologist 45(5): 599-611.

Cushman, Philip (1995) Constructing the Self, Constructing America. Menlo Park, CA: Addison-Wesley.

Dreyfus, Hubert (1991) Being-in-the-World: A Commentary on Heidegger's Being and Time, Division I. Cambridge, MA: MIT Press.

Dreyfus, Hubert \& Wakefield, Jerome (1988) 'From Depth Psychology to Breadth Psychology: A Phenomenological Approach to Psychopathology', in S. Messer, L. Sass and R. Woolfolk (eds) Hermeneutics and Psychological Theory: Interpretive Perspectives on Personality, Psychotherapy and Psychopathology, pp. 272-88. New Brunswick, NJ: Rutgers University Press.

Emad, Parvis (1985) 'Boredom as Limit and Disposition,' Heidegger Studies 64(1): 63-78.

Freud, Sigmund (1964) Standard Edition of the Complete Psychological Works of Sigmund Freud. London: Hogarth Press.

Gergen, Kenneth J. (1973) 'Social Psychology as History', Journal of Personality and Social Psychology 26(2): 309-20.

Gergen, Kenneth J. (1991) The Saturated Self: Dilemmas of Identity in Contemporary Life. New York: Basic Books.

Guignon, Charles (2002) 'Hermeneutics, Authenticity, and the Aims of Psychology', Journal of Theoretical and Philosophical Psychology 22: 83-102.

Heidegger, Martin (1962) Being and Time. New York: Harper and Row. All references to this text use the original German pagination.

Heidegger, Martin (1966) Discourse on Thinking. New York: Harper Torchbooks. Heidegger, Martin (1971) Poetry, Language, and Thought. New York: Harper and Row. 
Heidegger, Martin (1973) 'Messkirch's Seventh Centennial', Listening 8(1-3): 40-57.

Heidegger, Martin (1977a) The Question Concerning Technology and Other Essays. New York: Harper and Row.

Heidegger, Martin (1977b) 'Building, Dwelling, Thinking', in D. Farrell Krell (ed.) Basic Writings, pp. 323-39. San Francisco, CA: HarperCollins.

Heidegger, Martin (1982) Basic Problems of Phenomenology. Bloomington, IN: Indiana University Press.

Heidegger, Martin (1995) The Fundamental Concepts of Metaphysics: World, Finitude, Solitude. Bloomington, IN: Indiana University Press.

Heidegger, Martin (1997) Plato's Sophist. Bloomington, IN: Indiana University Press.

Heidegger, Martin (1999) Contributions to Philosophy (from Enowning). Bloomington, IN: Indiana University Press.

Heidegger, Martin (2000) Introduction to Metaphysics. New Haven, CT: Yale University Press.

Heidegger, Martin (2001) Zollikon Seminars. Evanston, IL: Northwestern University Press.

Levine, Robert (1997) A Geography of Time. New York: Basic Books.

Lutz, Tom (1991) American Nervousness, 1903: An Anecdotal History. Ithaca, NY: Cornell University Press.

Nagel, Thomas (1979) Moral Questions. Cambridge: Cambridge University Press.

O' Malley, Michael (2005) 'That Busyness That Is Not Business: Nervousness and Character at the Turn of the Last Century,' Social Research 72(2): 371-406.

Russell, Bertrand (1956) Our Knowledge of the External World. New York: Mentor Books.

Schwartz, Barry (2000) 'Self-determination: The Tyranny of Freedom', American Psychologist 55(1): 79-88.

Seligman, Martin E. and Csikszentmihalyi, Mihaly (2000) 'Positive Psychology: An Introduction', American Psychologist 55(1): 5-14.

Simonton, Dean Keith (2000) 'Creativity, Cognitive, Personal, Developmental, and Social', American Psychologist 55(1): 151-8.

Taylor, Charles (1988) 'The Moral Topology of the Self', in S. Messer, L. Sass and R. Woolfolk (eds) Hermeneutics and Psychological Theory: Interpretative Perspectives on Personality, Psychotherapy, and Psychopathology, pp. 299-320. New Brunswick, NJ: Rutgers University Press.

Ulmer, Diane K. and Schwartzburd, Leonard (1996) Heart and Mind: The Practice of Cardiac Psychology. Washington, DC: American Psychological Association.

Vaillant, George E. (2000) 'Adaptive Mental Mechanisms: Their Role in a Positive Psychology’, American Psychologist 55(1): 89-98.

KEVIN AHO, PhD University of South Florida, is Assistant Professor of Philosophy at Florida Gulf Coast University. His area of research is contemporary European philosophy, particularly topics in existentialism, phenomenology, and hermeneutics. ADDRESS: Florida Gulf Coast University, 10501 FGCU Boulevard South, Fort Myers, FL 33965-6565, USA. [email:kaho@fgcu.edu] 